\title{
Feministic Analysis of the House of the Spirits
}

\author{
Tesia George ${ }^{a}$, V.M. Berlin Grace ${ }^{\mathrm{b}}$ and D. David Wilson ${ }^{\mathrm{c}^{*}}$ \\ ${ }^{a *}$ Deparment of English, Karunya Institute of Technology and Sciences, Coimbatore-641 114, Tamil Nadu, S.India ${ }^{b}$ Department \\ of English, Karunya Institute of Technology and Sciences, Coimbatore-641 114, Tamil Nadu, S. India \\ 'Department of Biotechnology, Karunya Institute of Technology and Sciences, Coimbatore-641 114, Tamil Nadu, S. India
}

Article History: Received: 11 January 2021; Accepted: 27 February 2021; Published online: 5 April 2021

\begin{abstract}
Begun in the nineteenth and early twentieth centuries, the feministic theory has manifested in a variety of disciplines including literature. The House of The Spirits written by the Chilean author Isabel Allende in 1982 depicts the struggle faced by women of different classes in different generations. Although the novel spans about fifty years of the life of Esteban Trueba, it is the women around him during distinct phases of his life that bring life to the novel. This study explores the patterns of women subjected to distress and misery because of the male subjects around them. The second wave of feminism which lasted roughly two decades finds itself in the vicinity of the movement. It is no secret that the writer wanted to portray the veracity of the society with revolutionary and conventional women. The work also portrays how women empower the spirits of others of their gender around them. This study challenges the belief that exceptional women who are constrained in their families because of their gender endure more grief till they become the best version of themselves.
\end{abstract}

\section{Key Words:}

Feminism, conventional escapades, gender politics, inspiration, empowerment, women suffrage, persistence.

\section{Introduction}

Generally known as the "world's most widely read Spanish novelist", Allende's works are known for their plots and magical elements. Both their biographical and historical sentiments can be determined in The House of the Spirits. As the author's 100-year-old grandfather was lying on his death bed, she wrote all the wistful memories of the past years which became the basis of the novel. Though it was difficult to get it published, it went on to become a best seller no sooner than it was launched.

\section{Feminism in The House of the Spirits}

Far apart from the usual, the book starts with the reference to a dog of an unknown breed, which they named Barrabas. The first character to be introduced being a dog and not a man or a woman suggests that the writer did not want to have given preference to a male or a female. Had the first character to be introduced to the reader been a man, it would not have sparked as a woman-centered novel. And had it been a woman, it would have been smirked at and labeled a feministic novel in the first read. The writer was very right to choose a character that was neutral to her idea. Much to the surprise, the same sentence at the beginning of the novel also comes as the last sentence of the novel. Although it mysteriously dies in the middle of the novel, the author brings the element of magic along with the introduction of the dog as it never stops growing. The dog was immune to poison with seemingly unlimited capacity for growth and the only way to eradicate it was if someone deliberately killed it. The death of the dog is unknown in the whole story even with Clara possessing the powers to see into the future and predict disasters. One reason that Clara was unable to see the disaster beforehand was probably to show that women do not have all the answers. With the line "Barabbas came to us by sea"(Allende, 1982, p. 1), the author has wrapped up the whole story in a bow that connects the past events with the present events after three generations.

Clara's announcement that there was going to be an accidental death in the family was not taken much seriously at the moment. It wasn't until later that the poison meant for her politically active father killed Rosa instead that her family began to take her predictions seriously. Being felt responsible for the death of her sister, Clara remained mute for nine long years with every failed attempt by her parents and Nana trying to get her to talk. Had society accepted her predictions and stayed clear of any weapons that could take an innocent person's life, a lot of disasters in the future could have been avoided. According to Solnit, being unable to tell your story is a living death which is exactly what happened to Clara who thought that her prediction was what killed her sister and reserved herself to keeping mum for nine years.

People who have experienced traumatic events in their lives want to connect and feel and understand them, but often the risk of rejection and the subsequent shame and guilt are too powerful. (Silence and Trauma | Psychology Today)

Although Clara remained mute for a long time, she never failed to update every detail of her day-to-day life in her journals. It is said that trauma can silence a person for fear that he or she might not be accepted or 
forgiven for what they did. The only thing that she spilled all her secrets to was her journal which she was sure would never judge her back. Her muteness affected her family members who did not know what to do to make everything right. After a while, they stopped trying and accepted her as she was. It wasn't until almost ten years later that she opened her mouth to agree to her betrothal to Esteban Trueba who was engaged to Rosa before her death.

Rosa's death had disturbed Esteban's mindset similar to Clara's. He had his way of grieving. He left his job at the mines and went to Tres Marias, a ruined property that belonged to his family. He dealt with his pain by resorting to reshaping the property back to life. Although he appeared normal to the people working on his property, he was very easily irritated and wrathful. The tenants at Tres Marias were afraid of him and hated him to the core, but never dared to raise their voice. Chemtob, Novaco, Hamada, Gross, and Smith in their 1978 study had found that "anger is also a common response to events that seem unfair or in which you have been made a victim". It was due to the loss of the woman he loved that he shifted his focus to momentary pleasures and engulfed to raping the women who were working on his property.

Pancha Garcia was a girl of fifteen when Esteban found her in the fields and raped her. She neither resisted nor screamed because it was the same fate of her mother and her mother's mother that got repeated. When she too failed to raise her voice, she became the victim of those who raped her mother too. When she got pregnant by the patron, it set in motion a chain of events that would end up in bloodshed. Her grandson would later rape Esteban's grandaughter for revenge.

In this patriarchal and gendered world, rape is a stigmatized crime wherein aspersions are cast on the victim instead of the accused. This emboldens menfolk who bank heavily on a woman's silence to preserve her honor. It is also very easy to blame the woman for bringing out the worst in a man. (Carr)

Women who are victims of rape usually end up choosing to live with their unfortunate episode for fear of being unaccepted in society. Although everyone in the Tres Marias knew that she was pregnant because of the patron, they said nothing nor did they retaliate when the same fate repeated with other women of the property. They simply feared the man in power.

When Pancha's brother Pedro Segundo Garcia saw that she was pregnant, he simply walked away bowing his head to the ground, indicating that she was going to have to live with this. Nobody supported the women who were victims of Esteban's tantrums. It is the society that should stand up for those who cannot stand up for themselves. Pancha Garcia died in poverty and despair.

Esteban Trueba had retired to brothels on many an occasion even during his marriage while his wife was pregnant. He had also lost count of how many bastards he had had with the women in Tres Marias. But when his daughter fell in love with a man who was not of his class, it made him furious. His daughter Blanca was sure that her father would never accept Pedro Tercero Garcia who was the son of one of the tenants in Tres Marias.

When their affair came to light, Esteban was minutes away from killing her lover. He also whipped his daughter so hard that she bled. When the matter reached Clara, she questioned him why he was so upset with his daughter for what she did for love which he did for pleasure. Although Esteban did not know that his wife was aware of his poor choices, he hit her so hard that her teeth came off. This was what drove Clara to her second period of silence. She vowed never to speak to Esteban ever again.

In the novel, women are portrayed to be ambitious. Even prostitutes are shown to have ambitions. When Esteban Garcia met Transito Soto for the first time, she charged him fifty pesos for her service. When Esteban said that it was too expensive, she replied that she needed the money to take the train to the city and become rich. Eventually, she succeeded in becoming rich and also was able to pull the strings to get back Esteban's granddaughter back to him when she was captured and taken in for questioning. At that point in the novel, the author has added in the irony of stooping somebody as proud as Esteban Garcia to the need of asking a prostitute to help him in his crisis. The author gave voice to all the silent women in Tres Marias when Esteban bowed his head in shame in his latter days.

When Clara acted on her childish innocence and commented on a sermon given by Father Restrepo during the congregation, everyone expected the worst for the child. Her father hurriedly pulled her by the neck and dragged her out before the priest could give a more severe rash, and who called her 'possessed'. In the famous work The Canterbury Tales by Geoffrey Chaucer, he mentions five clergies and how they have portrayed the best version of themselves to the outside world while hiding their true colors.

Geoffrey Chaucer's The Canterbury Tales certainly gives its readers a multitude of hypocritical clergy members who seem more focused on worldliness than the spiritual plane. (The Corrupt Clergy in Chaucer's The Canterbury Tales - A Bookworm in The Bronx)

Father Restrepo is shown to be extremely strict in the matters of sin and discipline. He shows the best version of himself fearing that he is watched all the time by the people which would prove him to be a hypocrite and thereby lose his status. Although fear is man's worst enemy, in a way it is fear that drives a person to be on their best behavior. People resist doing wrongs for fear of being judged, punished, and humiliated, and so on. The priest being an extremist, made his people rather disciplined despite fear. The only person to be terrified by his words was Clara's father who thought that even in the age of science and technology, people would still view his daughter as a 'possessed' one. He felt that it would even affect his political career. 
The priest calling the child possessed in the middle of the sermon for disrupting his sermon can be viewed as a sanctimonious man who is using his people-given power to show that he is superior to others. Most of the people whom he corrected publically during his sermon were women. Some even had no idea what he was accusing them of. It shows how he used his power to insult women in a disgusting way where they came for salvation. The whole community started viewing Clara as a weird being after the priest called her possessed. The only person who forgot about it was Clara herself who wrote it in her journal and forgot all about it.

The art of writing serves many purposes, one of them being the permanence of memory. Clara wrote on her diary on most occasions, but 'forgot' them after penning it. At the moment her purpose would have been to pen it down before she 'forgot' about them completely, but as she never intended to read it again, she made them a journal of reference which the narrator later referred to in her later life reliving memories of terror. This also shows that women can turn to write to hide their pain, share the thoughts that the society around her would not understand, and that her word would matter one day.

Clara had turned down the idea of naming her son the name of his father and also did not permit her daughter Blanca to name her granddaughter Clara. Both the times, her justification was that it would be confusing if names were repeated in her journal. It showed how much significance she gave to her writing. All the times she reserved herself to muteness, she never failed to write down her thoughts.

Psychologists who discovered the "Bridget Jones effect" said it worked whether people elaborated on their feelings in a diary, penned lines of poetry, or even jotted down song lyrics to express their negative emotions. (Timmermans, Coenen, \& Bulck, 2019)

Writing has proved to improve moods, regulate normal behavior, and also reduce stress. The author has tried to portray that amidst all chaos, a woman can write elegantly if she chooses to do so.

Another important female character is Ferula, Esteban Trueba's sister who spent her whole life as a spinster. Ferula spent her whole life taking care of their sick mother. Despite her sadness in life, she made sure to tend to the needy. When Clara was engaged to Esteban, Ferula took her to a nice hotel to talk about the planning. Without speaking a word to her, Clara read her mind and told Ferula that she could come to live with her and Esteban at Tres Marias. The love and intimacy showed to her made her cry for never being given significance at anything. The day after Rosa's death, Esteban told her that he would be leaving the city. She commented that she would have rather been a man so she could leave places too without being bound to it. She felt like she was chained to their house to do all the household chores and could never leave the place as she was past marriage age, all because she was born a woman.

One can see how a woman understands another woman's pain and does the needful to make her feel at home. Clara invited Ferula to Tres Marias after her marriage to Esteban. Both of them remained close like sisters, just as Clara had promised. Although Esteban did not like the new bonding, it wasn't until many years later that he found Ferula being overly attached to Clara, to the point of bathing her and applying oil to her pregnant womb. Esteban banned her from coming near his family again which made Ferula curse him that he would die lonely like a dog. She wasn't seen again for six years until the day she died.

Ferula's curse shows how much it tormented her heart to leave Clara and Blanca when they loved each other so deeply. Clara was so hurt she went into depression for a short period. Men have the power to determine who would stay at their homes and who cannot. Even though Clara tried to find Ferula in every nook and crook, she failed to find her as she did not want to be found. Although Esteban sent her monthly allowance, it was found at the time of her death that she never spent it. Money can never replace love or earn forgiveness.

\section{Conclusion}

Isabel Allende has used various women characters of different professions and different classes to throw significance on the often easily forgotten women. The novel which spans almost fifty years of the life of Esteban Trueba is made exciting only with the women he's related to. When he finally gathers enough strength to confess his love for Rosa, she dies tragically in accidental poisoning. After raping Pancha Garcia, her grandson takes revenge on his granddaughter. His wife whom he adored for all his life, spend years not talking to him. And the granddaughter he loved more than anybody was taken into custody and dealt with violently. Although most of his sufferings were the result of his own mistakes, he made a lot of people, especially women, very downhearted. In a patriarchal society where women were expected to be stereotypical, Allende portrays rebellious women who break bondages and struggle in finding their way to freedom.

\section{Reference}

1. Allende, Isabel. The House of the Spirits. New York: Bantam Books, 1986. Print.

2. Allende, Isabel - The House of the Spirits, www.isabelallende.com/en/book/house.

3. Chaucer, Geoffrey, and Jill Mann. The Canterbury Tales. London: Penguin, 2005. Print.

4. Solnit, Rebecca. "Silence and Powerlessness Go Hand in Hand - Women's Voices Must Be Heard| Feminism | The Guardian.” The Guardian, The Guardian, 8 Mar. 2017, https://www.theguardian.com/commentisfree/2017/mar/08/silence-powerlessness-womens-voicesrebecca-solnit. 
5. Carr, Russel. "Silence and Trauma | Psychology Today.” Psychology Today, https://www.psychologytoday.com/us/blog/tour-duty/201209/silence-and-

trauma\#: :text $=$ People $\% 20$ who\%20have $\% 20$ experienced $\% 20$ traumatic, and $\% 20$ guilt $\% 20$ are $\% 20$ too\% 20powerful.\&text=They\%20may\%20feel\%20isolated\%20and,connection\%20is\%20what\%20they\%20n eed. Accessed 26 Feb. 2021.

6. Chemtob, C.M., Novaco, R.W., Hamada, R.S. et al.Anger Regulation Deficits in Combat-Related Posttraumatic Stress Disorder.J Trauma Stress 10, 17-36 (1997). https://doi.org/10.1023/A:1024852228908

7. Carr, Russel. "Silence and Trauma | Psychology Today." Psychology Today, https://www.psychologytoday.com/us/blog/tour-duty/201209/silence-and

trauma\#: :text $=$ People $\% 20$ who\%20have $\% 20$ experienced $\% 20$ traumatic, and $\% 20$ guilt $\% 20$ are $\% 20$ too $\%$ 20powerful.\&text $=$ They\%20may\%20feel\%20isolated\%20and,connection\%20is\%20what\%20they\%20n eed. Accessed 26 Feb. 2021.

8. "The Corrupt Clergy in Chaucer's The Canterbury Tales - A Bookworm in The Bronx." A Bookworm in The Bronx, https://www.facebook.com/WordPresscom, 28 Feb. 2017,

9. https://emmamayor.wordpress.com/2017/02/28/54/\#: :text=Geoffrey\%20Chaucer\%27s\%20The\%20Ca nterbury\%20Tales, of\%20their\%20crimes\%20and\%20flaws.

10. Timmermans, E., Coenen, L., \& Van den Bulck, J. (2019). The Bridget Jones effect: The relationship between exposure to romantic media contents and fear of being single among emerging adults. Psychology of Popular Media Culture, 8(2), 159-169

11. Sample, Ian. "A Diary Makes You Happier and Helps Brain Cope with Emotional Upsets, Psychologists Say | Science | The Guardian.” The Guardian, https://www.facebook.com/theguardian, 15 Feb. 2009, https://www.theguardian.com/science/2009/feb/15/psychology-usa. 